\title{
VERDENS UAFKLARETHED
}

\author{
MIKKEL BILLE
}

„Her kommer hyggen,“ proklamerede Sussie. Bartenderen med affarvet blondt hår trådte hen mod vores bord på Café Langebro på Islands Brygge med et tændt fyrfadslys. Rummet var ganske vist oplyst af dagslyset, men et strømsvigt i hele Storkøbenhavn havde fjernet al den supplerende elektriske belysning en tidlig eftermiddag i september 2003. Der sad vi, et par akademikere afbrudt $i$ arbejdet på kontoret af teknologiens uberegnelighed, og fik præsenteret et udsagn om verdens beskaffenhed, hvor lys og hygge smelter sammen til hyggelys. Under mit igangværende feltarbejde om belysningens sociale rolle i iscenesættelsen af rum møder jeg ofte udsagn som dette, hvor begrebet hygge og objektet stearinlys såvel som generelt dæmpede lyssætninger ikke adskilles.

Hvis man skulle følge den såkaldte ,ontologiske vending“ inden for antropologien med dens insisteren på (i visse tilfælde) at tage informanternes ord for pålydende, kunne man fristes til at sige, at stearinlyset ikke reprcesenterer hyggen, men er hyggen. Holbraads (2007) famøse sammensmeltning af materie og begreb i form af pulvermagt findes her i skikkelse af hyggelys. Det, der kommer på bordet, er rent faktisk hygge, hvis man tager Sussies udsagn for pålydende. Et hyggelys, der former en særlig atmosfære, der i forskellig grad værdsættes i Danmark.

Sussie står på ingen måde alene med en verden, hvor begrebet hygge smelter sammen med det materielle fænomen lys i ord som „hygge“ eller „hyggelys“. På reklamer for lamper forekommer udsagn som „tænd for hyggen“. I disse krisetider kan man købe „12 måneders rentefri hygge“ $\mathrm{i}$ form af en brændeovn, og $\mathrm{i}$ boligmagasiners mange reportager fra hjemmet sammensmelter begreber som hygge og materielle fænomener hyppigt som lys i én figur. Vi har altså i noget så almindeligt som stearinlys øjensynligt en dansk pendant til sammenstillingen - eller den manglende adskillelse - mellem begreb og ting, som ligger til grund for nylige diskussioner af „multiple ontologier“. 
Er der så tale om „flere verdener“ her på Café Langebro tæt på hjertet af København? Analysen kan måske virke søgt, når den omhandler situationer, som de fleste af os nok kan nikke genkendende til fra vores egen dagligdag, og man kan naturligvis indvende, at det er en rent sproglig vending, der reducerer såvel hygge som lys. Og dog tager jeg jo blot mine informanters, Sussies, reklamebureauers, journalisters og andres ord om tingene for pålydende: „Her kommer hyggen.“

I mange af den såkaldte ontologiske vendings mest promoverede eksempler inden for antropologien virker folk - antropologerne inklusive - afklarede om verdens beskaffenhed. Selv Sussie virker klar i mælet, og de „12 måneders rentefri hygge" lader til at kunne bibringe en afklaring i hvert fald det næste års tid. Samtidig er der dog en kurre på tråden, som også Lars Højers spørgsmål i dette temanummer af Tidsskriftet Antropologi (Højer 2013) tager fat på, nemlig spørgsmålet om uafklarethed. I de etnografiske udredninger af informanternes ontologi(er) - og dermed verden(er) - er der ikke mange udsagn som ,jeg tror, vi måske ser verden som ...“, „,den kunne måske være dette“, eller ,jeg ved det ikke helt, men måske ...". Man kan fundere over, om det er, fordi disse usikkerheder ikke blev udtalt af informanten, eller fordi de ikke blev skrevet frem i antropologens arbejde senere hen. Det synes, som om afklaring og radikale udsagn er interessante - vaghed og ubestemthed mindre relevante. John Law peger med begrebet afklarethed (definiteness) (2004:24f.) på, at videnskaberne, socialvidenskaberne inklusive, ofte anser manglende klarhed for et metodisk problem på forskerens side snarere end en præmis for informanternes forståelse af verden. Men hvad nu, hvis det rent faktisk forholder sig omvendt, som også Law peger på? Hvad nu, hvis informanterne ikke er helt afklarede i forhold til, hvad den enkelte ting eller verden som helhed egentlig er? Hvad nu, hvis den enkelte ting på samme tid kunne være flere ting for det enkelte individ og ikke kun forskellig for forskellige personer? Eller hvad nu, hvis informanterne oplever, at de ord, de har til rådighed - og som antropologerne griber - ikke er fyldestgørende nok til at beskrive deres verden?

Med udgangspunkt i disse spørgsmål om uafklarethed handler denne artikel om lys og atmosfære og disses rolle i udformningen af verdens beskaffenhed. Målet er dog ikke som sådan en etnografisk analyse eller udredning af, hvordan „hygge“ bruges i alle dens varierende sproglige og praktiske former, ej heller en analyse af dens sociale konsekvenser (se Linnet 2011). Målet er snarere at diskutere det metodiske aspekt $i$ at undersøge „verdener“" og „ontologier“ $i$ forhold til informanternes uafklarethed.

Artiklen peger på, at det $\mathrm{i}$ undersøgelsen af informanters verdener er relevant ikke blot at tage deres ord for pålydende, men også at tage deres uafklarethed for pålydende for at udforske den måde, verden snarere udfolder sig med vaghed 
og modsætninger som præmis. Først tager artiklen fat på en problematisering af fremstillingen af informanternes afklarede verden som egentlige ontologiske udsagn. ${ }^{1}$ Denne kritik bruges dernæst til at undersøge uafklarethed som position for analyse af brugen af lys. Slutteligt peger artiklen videre fra diskussioner om, hvad verden er, til hvordan den er, ved at tage fat på fornemmelsen af at vaere et sted: atmosfæren. Denne fornemmelse træder til tider ud over sprogets muligheder og sågar opmærksomhedens retning, men ikke desto mindre former den måden, hvorpå verden fremtræder for såvel informant som antropolog og dermed deres forståelse af den. Atmosfære kan således forstås som en slags ,tåge“, der indvirker på erfaringen af verden. For at forstå informanternes (og antropologernes) verden argumenterer artiklen for, at atmosfærebegrebet må indgå i det antropologiske arbejde, da det former såvel informanternes afklarethed som uafklarethed om og i verden. Artiklen er baseret på et igangværende feltarbejde i Jordan og Danmark om introduktionen af energibesparende lysteknologier. ${ }^{2}$

\section{Afklaringens aspekter}

I redaktionens oplæg til dette temanummer af Tidsskriftet Antropologi får man fornemmelsen af, at den såkaldte „ontologiske vending“ og diskussionen af multiplicitet primært handler om folk i fjerne egne. Diskussionen handler her mest af alt om heksedoktorer i forskellige afskygninger, og den er blandt andet sat i gang af Henare, Wastell og Holbraads bog Thinking Through Things (2007) med udgangspunkt i Viveiros de Castros (1998) arbejde med perspektivisme i Amazonas. Hvis vi imidlertid anlægger et lidt bredere perspektiv end blot det antropologiske miljø, finder vi studier, der arbejder med spørgsmålet i andre kulturelle og geografiske kontekster. Der har været en lang række indflydelsesrige studier af ontologier og multiplicitet med udgangspunkt i Science and Technology Studies, der strækker sig fra analyser af fertilitetsklinikker i USA (Cussins 1996), sundhedsfarer ved prævention i Australien (Dugdale 1999), får med mund- og klovsyge (Law \& Mol 2008), alkohollever i England (Law \& Singleton 2005), vandpumper i Zimbabwe (Laet \& Mol 2000) til analyser af åreforkalkninger i Holland (Mol 2002).

I sidstnævnte studie viser Annemarie Mol på fremragende vis, hvordan et objekt, åreforkalkninger, som en komposition af elementer faktisk er forskellige objekter for forskellige mennesker. Der er altså ikke blot tale om, at der findes forskellige perspektiver på samme objekt. Mol folder sin etnografi ud gennem flere års studier af hospitalpersonalets håndtering af sygdommen, beskrivelser i journaler, medarbejdermøder osv. Når Mol observerer og taler med patologen, er åreforkalkning en fortykkelse af årens inderste membran. Det 
er, hvad åreforkalkning er. Når hun derimod taler med lægen i ambulatoriet, er åreforkalkning en smerte eller immobilitet. Åreforkalkninger i benene er gangsmerter, svag puls, kold hud, lavt blodtryk. Således undersøger Mol, hvordan forskellige fagfolk på hospitalet hver især anskuer forskellige sameksisterende objekter, netop fordi sygdommen bliver til og indgår i forskellige praksisser (eksempelvis op.cit.24f., 30, 102, 108-110). Virkeligheden bliver enacted, eller på dansk, den ,gøres“, „praktiseres“ eller „,udspilles“. Hvis der er fire forskellige praksisser omkring åreforkalkninger, er der fire forskellige åreforkalkninger og ikke bare forskellige perspektiver på det samme fænomen. Disse virkeligheder er dog ikke nødvendigvis fragmentarisk adskilte, men folder sig ind og ud af hinanden. Kroppen (i ental), siger Mol, er med andre ord multipel (mange) (op.cit.5, 84; se også Law 2011).

I Mols multiplicitetstilgang er et objekt altså, hvad det gør og gøres til. Martin Holbraad taler ligeledes om, at begreber og ting er sammenfaldende: at alle de måder, hvorpå informanter handler med eller taler om det, de gør med eller ved ting, er måder, der definerer tingen, snarere end blot repræsentationer af den (Holbraad 2010:12; se også Bijker 1995:77; Gad \& Jensen 2010). Trods forskelle mellem, hvad man kan kalde Mols ,,performative tilgang“, hvor ting praktiseres, og Holbraads „repræsentation-præsentations“-tilgang, hvor ting og begreb sammensmelter, har de den analytisk potente idé til fælles, at ting er foranderlige og ikke mindst multiple. Hvad et objekt er, bliver til et spørgsmål om, hvorvidt og hvordan man ved noget om og gør noget ved objektet, hvormed „spørgsmålet om objekter bliver til spørgsmålet om en særlig relation mellem menneske og objekt" (Bryant 2011:16; oprindeligt en central pointe for Appadurai 1986).

Multiplicitetstilgangene rejser dog nogle kritikpunkter. Det kan eksempelvis forekomme problematisk, at folk transformerer objekter i forhold til de praksisser, de indgår i, da det må betyde, at objektets kemiske struktur også er forandret (jf. Sartre 1977:65). Ydermere kan man indvende, at selvom de fleste studier af multiplicitet handler om informanternes praksis med ting - og ikke blot er en afart af diskursanalyse, hvor ord skaber verden - bliver den skriftlige argumentation ofte bundet op omkring klare sproglige udsagn: „Vi lever i de verdener, vore forfædre lader os se“ (Nielsen 2013:23) eller patologens: „Se. Der er din åreforkalkning. Der er den. En fortykkelse af membranen“ (Mol 2002:30, se også 1999:77f.). Man kan spørge, hvordan et antropologisk studie af multiple ontologier egentlig ville se ud, hvis man ikke havde sproglige udsagn som udgangspunkt eller til at underbygge med. Det er alt andet lige nemmere at overbevise læseren og sig selv og i det hele taget tage spørgsmål om ontologi op med Sussies „Her kommer hyggen" end alene at basere sig på en detaljeret beskrivelse af praksis med ting (se også Alberti et al. 2011). Samtidig ligger der også noget centralt i ordene: Selve 
ordet „åreforkalkninger“ ansporer (i hvert fald på dansk) til, at objektet må eller kan indeholde en åre, der er forkalket. Det er muligt, at lægen i ambulatoriet på det hollandske hospital ikke kan bruge det til meget i sin diagnostik og igennem sin praksis ikke forholder sig til dette, men der må alligevel være en eller anden form for bevidsthed om, at åreforkalkninger kan være noget andet end blot svag puls og kold hud.

Ludwig Wittgenstein (2009:205) taler således om aspektbeskuelse, når han viser, hvordan en tegning kan ligne både en kanin og en and, alt efter hvordan man ser den. Hvis informanten er vel vidende, at det samme objekt kan fremtræde i flere former, hvordan kan man så lægge informanterne i munden, at det er en tegning af en kanin, alene fordi de momentant (fx i kraft af deres faglige erhverv) kun ser denne for sig eller er tvunget til at handle på den, som om den kun var det ene objekt (samme kritik kunne bruges om Law \& Mol 2008)? Lægen, der i såvel ord som praksis skaber åreforkalkninger som svag puls, må gennem sin uddannelse være kommet i kontakt med ideen om, at åreforkalkninger er, ja, forkalkninger af åren.

Ifølge Mol kan samme person da også glide mellem den ene og den anden praksis (Mol 1999:79). Men hvis informanten således er i stand til at glide mellem versioner af åreforkalkninger eller blodmangel (op.cit.77f.), betyder det dermed også, at hver version i et eller andet omfang må have en (momentant) afklaret helhed. Mol hævder eksplicit, at det er versioner og ikke aspekter, informanten „gør“ (op.cit.83). Men evnen til at glide mellem den ene og den anden version såvel i praksis som $\mathrm{i}$ bevidstheden om versionernes sameksistens synes for mig netop at pege i retning af aspekter, jf. Wittgenstein, snarere end i retning af forskellige versioner. Der er altså tale om en forskel mellem at tage udgangspunkt i afgrcensede og afklarede versioner i forhold til mere flydende og uafklarede aspekter.

Om end jeg billiger Mols tilgang til materialitetspraksis, er pointen her dog at fremhæve en mere generel problematik ved studier af multiple ontologier, der tager udsagn for pålydende som helhedsudsagn, når informanten måske netop kun udtaler sig om et aspekt eller ikke er afklaret. Og hvor ofte er informanterne egentlig afklaret? For mig vil det at lægge en for stor vægt på informanternes momentane og klare udsagn som indgang til, hvad deres ontologi ,er“, være en radikalisering og paradoksalt nok en dekontekstualisering af den erfaring, der ligger forud for selve udtalelsen eller praksis.

På samme vis mener jeg, at det er problematisk at tage Sussies ord for pålydende uden samtidig at lytte til alle de andre måder, hvorpå hun også vil definere såvel lys som hygge, afhængigt af konteksten. Lys er både varme, hygge, farligt og bare lys, såvel adskilt som samlet i, hvad Edwin Ardener (1992) har kaldt samtidigheder 
af betydning, handling og objekt. Sussies hurtige og venlige åbningsbemærkning var et $u d s n i t$ af, hvad hun mente, lyset var i dette øjeblik, ikke helheden af, hvad hun forstår ved lysets værende. Min kritik går altså ikke på ideen om, at tingen „gøres" (om end ordet på dansk er problematisk), eller ideen om, at man i visse tilfælde kan tale om „multiple ontologier“ (Bille 2010). Jeg kritiserer derimod ideen om, at en ting kun er eller gøres til én ting ad gangen for en enkelt informant snarere end eksempelvis at udgøre et ikke afklaret antal aspekter af ting. En ting kan have flere aspekter for samme person, endda modsatrettede, og nogle af disse aspekter kan informanten være afklaret omkring eller bruge i sit erhverv og andre ikke. Men der er stadig en enhed i de aspekter - de er aspekter af én ontologi for den enkelte.

Endelig kan der også være midlertidige erkendelsesinteresser i spil, som handler om at give en retning for, hvorledes et objekt bliver indsnævret - momentant kategoriseret - i en given situation, for at kulturel praksis kan forløbe. Sussie „skaber" godt nok lyset som hygge, når hun kommer ned til et bord. Og hendes udsagn er forførende klart nok for os til at bide mærke i og indlede et akademisk argument med. Men Sussies udsagn, hvor lyset er hyggen, er ikke bare et udtryk for, hvordan verden er i netop dette øjeblik, men også et udtryk for en normativitet om, hvordan den skal være - en erkendelsesinteresse med en social validering af såvel cafébesøgets som det sociale samværs natur.

En ting kan altså være flere ting samtidig for den enkelte, og der kan være en bevidsthed som i Wittgensteins eksempel om, at en ting både er en and og en kanin. Men der kan også være en uafklarethed i, om lyset er hyggen: „Det er hygge, eller måske er hygge ikke det rigtige ord“, som flere af mine informanter udtaler. Hygge er jo et bekvemt ord at bruge, til tider en metafor, men ofte bruges det også i mangel af andre betegnelser for det væld af situationer, det forekommer i. Dertil kommer den sociale værdi, der ligger i udsagn om, at en begivenhed netop var præget af denne betegnelse. For disse informanter er lys og hygge $b$ åde det samme $o g$ forskellige ting, og hverken ensartetheden eller forskelligheden er de helt afklarede omkring.

Hvor meget for pålydende skal vi således egentlig tage vores informanters ord? Når informanterne mener eller gør noget, er der fare for, at det fortolkes radikalt, uden at der tages nøje højde for, at ordene, de anvender, måske ikke er fuldt dækkende for det, de taler om, men blot er en vant sproglig vending. Én pointe er således her, at jeg kan tage udsagnet „Her kommer hyggen“ for pålydende som et afklaret ontologisk udsagn, der indgår helt almindeligt i sproget i mange andre interviews, hvor informanter sammensmelter hygge og lys. Men jeg kan også tage det for meget for pålydende, da de også senere vil sige, at det måske ikke helt er sådan alligevel, eller i hvert fald, at det også er noget andet, og alle 
disse variationer er således del af én ontologi. I mit feltarbejde om belysning på Islands Brygge er disse spørgsmål om uafklarethed mindst lige så relevante som den stålsatte identifikation af, hvad noget er.

\section{Lysets væsen}

Mine studier af lys tager udgangspunkt $\mathrm{i}$ indførelsen af energibesparende teknologier i Danmark og Jordan. I Danmark har udfasningen af glødepæren betydet, at kvaliteten af elektrisk lys har ændret sig - ifølge mange danskere og lysforskere til det værre. De energisparende pærer er dyrere, og for mange personer lever de ikke op til kulturelle forestillinger om hygge og hjemlighed knyttet til dæmpet belysning og rødlig glød. Dette sker, til trods for at elsparepærerne taler til et etisk forbrug i klimateknologiens æra.

I Danmark lyder en ofte anvendt vending, at ,lys er liv“. Men det er i halvmørket, vi lever. Dette stiller særlige krav til de lysteknologier, vi anvender. Med de nye teknologier er der kommet øget opmærksomhed på lyskvalitet, fordi lyssætningen nu ofte viser sig at være marginalt anderledes end den visuelle komfortnorm, som glødepæren har skabt gennem det seneste århundrede. Alt imens vi som almindelige forbrugere tidligere paradoksalt nok forstod lysmængde med en betegnelse for energiforbrug, watt, er et nyt begrebsapparat blevet formet i forlængelse af det politiske pres for øget energibevidsthed. Vi skal således nu som forbrugere forstå lys og købe pærer i forhold til lumen - en måleenhed for lyskvantitet.

For mange danskere er det dog ikke så meget lyskvantitet, som det er lyskvalitet, der er pointen. Stearinlys tændes, når gæster kommer, de går ud, nye sættes op, det elektriske lys dæmpes og øges, når folk skal gå hjem, og gardiner trækkes for, som natten falder på, og vinduerne fremstår som mørke flader. Som en informant pointerede: „På mange måder er belysning bare noget, man gør.“ Teknisk set kan de energisparende pærer sjældent dæmpes, de tænder langsomt, og æstetisk har selve pæren et andet udtryk, der måske slet ikke passer ind i lampedesignet. Ydermere udsender de ikke samme lysspektrum som glødepæren, hvorved overflader fremstår anderledes i såvel farve som tekstur. Ofte vil en overflade fremstå uden dybde og med mere grålig tone. En glødepæres farvetemperatur er på 2700 kelvin, som betyder, at den er mere rødlig end elsparepæren, der ofte er på over $2900 .{ }^{3}$ Ligeledes er farvegengivelse væsentligt forskellig, hvor glødepæren har en såkaldt $r a$-værdi på 99 i forhold til solens 100, mens en normal energisparepære ligger omkring 80-85. Som mediatorer for perception har den tændte pære således indflydelse på, hvordan materialer såsom stof på møbler og teksturen i træ fremstår, og knytter dermed også an til forestillinger om æstetik og hjemlighed. 
Omvendt er jordanerne i mit feltarbejde glade for lyset fra de energisparende pærer. Sammen med de allestedsnærværende neonrør giver de et stærkt klart lys, er billige i brug og lever op til praksisser i hjemmet. Jordanernes forestillinger er forankrede i andre ideer om hjemlighed og gæstfrihed (Bille \& Sørensen 2007) såvel som imitation af solens gang på himlen. I Jordan er der korte overgange mellem dag og nat i modsætning til den rødlige glød fra aften- og morgensolen, der toner verden længere i Danmark. I modsætning til, hvad der er tilfældet i Danmark, er de jordanske hjem altså svøbt i skarpt lys, hvor mørket og skyggerne kun i begrænset omfang har plads.

\section{Sprogets begrænsninger}

Det er i dette spændingsfelt mellem meget lys i Jordan og lidt lys i Danmark, at lys, skygger og mørke træder frem som studieobjekt. Lys tages ofte for givet som noget, vi ser $i$, men ikke i sig selv ser. Michael Gilsenan beskriver således i Recognising Islam (Gilsenan 1982:266), hvordan han forsøgte at forstå meningen med et islamisk sufiritual for ihukommelsen af Gud i en moske i Kairo. Han havde store problemer med at pege på, hvad det var, der slørede hans forståelse. Det var ikke de sproglige mangler $i$ hans arabiske eller problemer med at følge hymnerne. Hans problem var derimod neonlyset. Hele vejen rundt i moskeen var vers fra Koranen bøjet i neon: grøn neon. For ham var det dog ikke farven, men neonen, der forstyrrede. Det var som en tone i en symfoni, der konstant ramte forkert og fjernede al ro og balance i hans krop. Efter otte eller ni måneder kiggede han en dag på et tidspunkt væk fra de vuggende kroppe i ritualet og rytmerne og så - ikke neon - men bare en grønhed, der ikke „repræsenterede noget andet“. En grønhed, der ganske enkelt var potent i kraft af sig selv. Fra dette ureflekterede og uventede øjeblik ophørte han med at se neon. Han så i stedet den direkte oplevelse af grønhed, som „bare $e r^{\prime \prime}$ for hans muslimske informanter på en særlig almindelig måde - en måde, der både er den samme som og forskellig fra hans egen (ibid.). For antropologen, der søgte at forstå de muslimske informanters verden, blev ni måneders uafklarethed og manglende evne til at sætte sig ind i informanternes verden og forstå dem stedt til hvile, da erfaringen af væren forandredes fra neon til grønhed.

Ligesom Gilsenan beskriver det, har mine jordanske informanter i en landsby i Sydjordan også kun i yderst sjældne tilfælde kunnet sige noget om det elektriske lys fra elsparepærer eller lysstofrør, der bevæger sig ud over, at de har dem, fordi de er billigere og giver et klarere lys. Og dog har jeg at dømme ud fra deres lyspraksisser en fornemmelse af, at de også har en markant anderledes forståelse af, hvad lys er, og ikke mindst hvad det gør for resten af deres inventar. 
Halvdelen af husene i landsbyen har fået installeret grøntonede vinduer, der bader rummene i grønt lys om dagen. Når jeg vågnede op om morgenen, var rummet badet i grønt lys på en for mig særdeles uvant måde. Én ting er neonlyset, som Gilsenan også faldt over. Det grønne lys, der skinnede gennem mødet mellem sol og vinduets toning, er trods alt noget andet. Og dog er det netop grønheden, der er pointen. Nærmest som Olafur Eliassons Tågetunnel, hvor man træder ind i en tunnel oplyst af farvet lys i en tæt tåge, var det en færden i et overfladeløst rum af grønhed, der tonede alting. Overflader forsvandt til fordel for kroppens erfaring af øjeblikkets stemthed (se også Schmitz 2011; Schmitz et al. 2011). Oftest er responsen på spørgsmål om de grønne vinduer blot, at det var de vinduer, informanterne fik, da de afgav bestilling, og at det i øvrigt da er en pæn farve. Eller måske, at vinduerne holder solens varme ude, men at det ikke var noget, informanterne på nogen måde tænkte over. Antydninger af, at den grønne farve kunne have religiøse undertoner, blev ofte forkastet trods den tætte forbindelse mellem farven grøn og islam.

De jordanske informanter enten kan ikke eller vil ikke forholde sig til, hvad lyset er eller betyder. Erfaringen ligger ud over sprogets betydningsperspektiv (Gumbrecht 2004), men ikke desto mindre „er den bare“ for såvel Gilsenans informanter som mine egne. Havde informanterne nu bare udtalt sig i en kort, klar sætning, „det grønne lys er Guds velsignelse“, havde det været lettere at argumentere for „flere verdener“, men det gjorde de ikke. I stedet må jeg lade lyset være et affektivt nærvær, der ikke refererer til noget andet, men trænger sig kropsligt og affektivt på (Armstrong 1971).

Lyset fra elpæren og det grønne lys fra vinduet forstærker nogle materielle egenskaber, alle ting har i deres visuelle fremtrædelsesformer. Tag eksempelvis et blåt glas: Hvis glasset er placeret alene i et hvidt rum, vil det fremtræde væsentligt mere markant for beskueren og som affektiv oplevelse, end hvis det er placeret som et glas blandt mange glas. Læg dertil, at glasset både vil kaste skygger og ændre farven på omkringliggende genstande (Böhme 1995:32; Bille \& Sørensen 2012:104-09). En tings væren er altså i dette perspektiv ikke begrænset til dens fysiske form og afgrænsning. Tingen kan træde ud over sig selv - være „ekstatisk“ i filosoffen Gernot Böhmes terminologi (1995:32-34, 2001:131-45). Med ideen om tingenes ekstase bliver en genstands væren udfoldet til mere end blot dens fysiske materielle afgrænsning eller den måde, hvorpå mennesket „gør“ den. Tingsligheden bliver den måde, hvorpå tingen toner og tones af andre ting, og dens affektive egenskaber (se også Navaro-Yashin 2012). 


\section{Hyggens vaghed}

Modsat min erfaring fra Jordan er det ikke svært at tale med folk i Danmark om lys. De taler oftest om hygge, om samvær, om forbrug og om hjemlighed. Eller om det dårlige „kolde lys“ fra elsparepærer, der ændrer tingenes fremtrædelsesform i hjemmet. Stort set alle sondrer mellem ,,praktisk lys“ og „hyggelys“, afhængigt af om det er i køkkenet eller i stuen, eller afhængigt af de aktiviteter, de foretager sig, hvor lysmængden og fordelingen i rummet skrues op eller ned. Lyset bruges omskifteligt til at skabe de aktiviteter og den atmosfære, der ønskes. Selv når folk er alene, bruges lyset til at skabe en specifik atmosfære eller ligefrem forestillinger om, at man ikke er så ensom, som man måske kunne føle sig. En informant udtaler således, hvordan hun bruger lyset til at skabe en tilstedeværelse ud over sin egen. En anden informant tordner mod hyggelyset og bruger afvisningen aktivt til at vise, hvem han er og vil være, mens en tredje tænder lyset, fordi han ved, at det behager hans partner. Lyset er med andre ord tæt indlejret i forståelser af, hvordan man er social, og giver mulighed for, at rummet fremtræder i en særlig form.

Stearinlyset haren anden stoflighed end glødepærer, selvom farvetemperaturerne for de to måske kan minde om hinanden. Stearinlyset har en diffus og flygtig tingslighed, der skaber rummet på en anden måde end det mere statiske elektriske lys. Ardener hævder ligefrem, ,,at for at den danske domesticitet kan aktiveres, skal der være et stearinlys“" (Ardener 1992:28). Dette er dog langtfra tilfældet blandt mine informanter. Uagtet forskelligheden i boligform, indretningsstil, indkomst og baggrund hæfter mine informanter sig ved, at dæmpning og afskærmning af det elektriske lys også kan være hygge. Det er den dæmpede belysning og gløden, der gør det ud for hyggelys, snarere end stearinlysets stoflighed i sig selv.

Lyset skaber et nærvær for informanterne. Den dæmpede belysning gør det altså ,hyggeligt“, og denne effekt af lyset bliver samtidig, hvad hyggen er eller også kan være. Som informanten Catharine kort bekendtgjorde i forhold til stearinlys: „Stearinlys er hygge. De giver hyggen“, hvorved hyggen artikuleres som både årsag og effekt. Stearinlys er hygge, fordi de skaber hygge, hvilket på sin vis bekræfter den performative tilgang til materialitet, ved at det er de måder, vi praktiserer tingene på, der definerer dem.

Lyset er såvel en markør, en aktivator for handling, et tegn og en sceneriskaber, der forvandler fysiske rum til sociale rum (Ardener 1992). Ardener kalder dette en samtidighed, hvor delelementerne ikke fører til, eller kommer efter, hinanden, men snarere kommer på én gang. Han beskriver en situation i Danmark, hvor en vært tænder stearinlyset, da gæsterne træder ind, for derefter at tænde et bål udenfor for at bringe bållysets varme, snarere end ildens temperatur, ind i stuen. Lyset bliver i det perspektiv en markør, der skaber de sociale rum, uden klar „betydning“"(op.cit.27; jf. Armstrong 1971:31f.). Samtidig med informanternes 
udsagn om hyggelyset følger dog en usikkerhed og videre refleksion over, om det nu også er sådan, verden hænger sammen. Informanterne færdes hele tiden $i$ et krydsfelt af afklaring og tvivl med en omskiftelighed mellem et ,patisk moment" af førbegrebsligt nærvær og grebethed og et ,gnostisk moment“ af begrebsliggørelse og klassificering af det iagttagne (Straus 1966:10).

Hovedformålet her er ikke en etnografisk analyse af forståelser af lys, beskrivelse af de mange praksisser, hvorved lyset skabes og skaber menneskers liv, eller for den sags skyld en multiplicitetsanalyse. Hovedformålet er at pege på uafklarethedens rolle. Jeg vil dog alligevel tage et par eksempler frem fra mine godt 60 interviews hjemme hos folk i Danmark for at illustrere det metodisk problematiske ved at bero for meget på afklarede udsagn såsom „,her kommer hyggen". Under de fleste af mine interviews skifter samtalen om, hvad hygge er, ofte mellem at pege på klarhed og at pege på vaghed. „Hygge er mange ting,“ som Nanna på Islands Brygge siger. „Men selvfølgelig siger man det der med, at stearinlys, det er også hygge. Det er det vel også. Det kan også gøre det. De kan sætte den der stemning. Der er noget ... ja ... man samles om.“"Men senere $\mathrm{i}$ interviewet siger Nanna:

Det er noget med, at jeg mentalt siger, at nu vil jeg gerne gøre det hyggeligt, og derfor tænder jeg det her lys. Så det er vel sådan ... at når jeg gør det her, så bliver det hyggeligt. Det gør det jo ikke. Det er jo ikke ensbetydende med, at det bliver hyggeligt - det ved jeg jo også godt ... Men rammen er ligesom sat for det. De ydre omstændigheder bliver sat, ved at man tænder det her stearinlys.

På den ene side lægger Nanna altså op til, at når stearinlyset tændes, eller mere generelt, når der er en særlig iscenesættelse af dæmpet belysning, så kommer hyggen. Efter videre refleksion kommer tvivlen dog ind: ,Jeg ved jo også godt, at det ikke er sådan“, hvorefter lyset bliver en rekvisit til at sætte en hyggelig stemning. Altså snarere end en del af en tings væren bliver det til en affektiv tilstand - en atmosfære - der opnås gennem tingen.

Mange informanter foretager umiddelbart en sammensmeltning mellem begrebet hygge og en særlig fremtræden af det materielle fænomen lys. Alligevel forbliver de uafklarede om, hvad hygge egentlig er, da ordet dækker for bredt. Eller rettere, hygge er flere ting: både fysiske ting, fremtrædelsesformer, samvær og atmosfære. På den ene side er hygge altså et begreb med meget vage definitioner. Det bruges på forskellige måder, i forskellige grammatiske former og til at betegne følelsen af alt fra et restaurantbesøg, et område af byen eller en ting til en stille aften alene hjemme (se også Linnet 2011). Hyggen synes defineret ved sin uformalitet, sit ideal om ligeværd og nedtoning af regler, samtidig med at hygge også i høj grad er struktureret og planlagt ganske grundigt - man 
fristes til at sige omhyggeligt - selvom det modsatte foregives (Ardener 1992: 26f.). På den anden side har hygge en meget tingslig karakter blandt mange af informanterne. Hyggen er forbundet med samvær gennem andre ting: mad, slik, fjernsyn eller at være alene med en bog og en kop te, hvor det materielle bliver mediet, igennem hvilket hyggen udfolder sig. Dette finder sted, samtidig med at lyset også er hyggen. Hyggen findes, om end dens karakter og form er uklar. Det er, som om informanterne erkender, at betegnelsen „hygge“ făr lov at dække over (for) meget i Danmark, hvorfor de ikke er helt afklarede i forhold til deres egen brug af ordet.

Det står i skærende kontrast til Jordan, hvor tavsheden omkring lys er slående, i betragtning af hvor meget lys der er. I eksemplerne fra Jordan og Gilsenans feltarbejde i Kairo dækker sproget ikke erfaringen, mens ordet „hygge“ i Danmark er for diffust og altomfavnende. Pointen er altså her, at for at forstå informanternes verden er det også nødvendigt at tage informanternes tavshed og uafklarethed for pålydende - hvis uklarheden og tavsheden vel at mærke er etnografiske træk. Måske viser tavsheden, at lyset - selv det grønne - bare „er“ på en helt særlig måde som patisk moment, der helt intimt er det samme som antropologens iagttagelse og dog forskellig. I samme omfang viser talen om hygge, at uafklaretheden omkring, hvad ordet egentlig dækker over, netop indfanger, hvad lyset er, og hvordan det former sociale verdener og tingenes fremtræden.

Ovenstående omhandlede spørgsmålet om, i hvilket omfang informanterne ser aspekter, har erkendelsesinteresser, er afklarede eller uafklarede, og hvorvidt sproget er dækkende til at fange dette. Næste afsnit peger derimod i en anden retning end spørgsmålet om, hvad tingen er (eller gøres til), som den ontologiske vending ofte har haft i centrum. I stedet peger jeg på måden, hvorpå ting fremtræder, som de gør, som element for forståelsen af, hvordan den ene eller anden verden formes.

\section{Atmosfærens væsen}

Når jeg drager lys ind som tema for forståelsen af menneskers verden, er det for at pege på den visuelle indflydelse, mørke, lys og skygger har på oplevelsen af verdens fremtræden. Denne fornemmelse og følelse af rumlighed går under betegnelsen atmosfære, der toner den måde, mennesker erfarer og fortolker begivenheder og steder på. Gennem disse toninger kan man opleve en opstemt, hadsk eller sørgmodig atmosfære, hygge, intimitet eller andre sådanne beskrivelser af situationer. Men atmosfære kan også forbigå ens opmærksomhed og ikke lade sig verbalisere, men stadig have indflydelse på verdens fremtrædelse og menneskers praksis i den. 
Ikke blot er folks verdener tonet af atmosfærer, men den antropologiske datagenerering er skabt i lyset af sådanne atmosfæriske stemtheder, hvad enten vi er metodisk opmærksomme på det eller ej. Rent metodisk søger antropologer ofte at skabe eller fange en atmosfære, som informanter er trygge i, eller som er særligt intensiv for at generere tillid og data (en balinesisk hanekamp eksempelvis). De atmosfærer, der har været forbundet med feltarbejde, forsøger vi efterfølgende med vekslende held at genskabe i artikler og bøger for at fange læseren. Atmosfærer er så at sige en integreret del af den måde, hvorpå ting og følelser træder frem, og analyser skabes (Geertz 1988). For at forstå informanters verdener må vi altså forstå den måde, hvorpå atmosfærer griber os og dem - hvordan atmosfæren kan være den fornemmelse, informanterne strukturerer deres samvær i forhold til. Til tider rækker de ord og begreber, man normalt bruger, ikke - som med „hygge“. Til andre tider strækker atmosfærer sig ud over sprogets grænser og er noget, der „bare er“.

Atmosfære er ikke blot et produkt af den menneskelige psyke. Arkitektur er eksempelvis et område, der søger at dirigere atmosfære og humør. Men atmosfære kan heller ikke reduceres til tingslige kvaliteter ved den materielle verden (Böhme 1995; Bollnow 1963; Tellenbach 1968). Mennesker kommer også med et humør, og det humør kan smitte (Brennan 2003). Hvis man er opstemt, kan denne følelse dæmpe sig, hvis man træder ind til en begravelse, og omvendt kan en tristhed forsvinde ved at træde ind i et rum med feststemte mennesker. Den tyske filosof Gernot Böhme argumenterer for denne relationelle afhængighed:

Atmosfærer fylder rum: De udstråler fra ting, konstellationer af ting, og fra personer $[. .$.$] . De kan ikke defineres uafhængigt af de personer, som bliver$ påvirket følelsesmæssigt af dem. De er subjektive kendsgerninger. Atmosfærer kan fremstilles bevidst gennem objektive foranstaltninger, lys og musik [...]. Men hvad de er, deres karakter, er altid noget, der skal føles: ved at udsætte sig selv for dem erfarer man de indtryk, de udøver. Atmosfærer er rent faktisk karakteristiske manifestationer af subjektets og objektets samvær (Böhme 1998:112-14).

Atmosfære er således en integreret del af det at være menneske i en materiel verden og ikke nødvendigvis noget, det er muligt at verbalisere. Atmosfærer „findes“, selvom de kan have såvel svag som stærk, positiv som negativ eller sågar ubetydelig indflydelse, og uanset om de kan beskrives eller ej. Verdens fremtræden formes således også af disse atmosfærer, den måde, rum griber os på, og vi griber de „stemte rum“ på (Bollnow 1963:230; Böhme 2006:16).

Når jeg inddrager atmosfærebegrebet her, er det således på grund af spørgsmålet om atmosfærers ontologiske status. Atmosfæren kan ikke peges ud, som i „dér er den“, og dog findes den (Heidegger 2007:161f.). Den er både en ontologisk realitet, der „findes“, og en analytisk implikation af at studere folks praksisser og 
forståelser af rum og samvær. De kan ikke præcist afgrænses til et værelse eller sted, men er omskiftelige, hvorigennem virkeligheden viser sig som en helhed med talløse nuancer uden retning og grænser (Gumbrecht 2006; Thibaud 2011). Atmosfære er noget kvasiobjektivt, for at anvende Böhmes terminologi (2006: 16), der netop er omgivet af en særlig form for uafklarethed:

Vi er ikke sikre på, om vi skal tillægge dem [atmosfærerne] objekterne eller omgivelserne, hvorfra de udløber, eller subjekterne, der erfarer dem. Vi er også usikre på, hvor de er. De lader til at fylde rummet med en scerlig følelsesklang som en tåge (Böhme 1995:22, min fremhævelse).

Et fokus på atmosfære betyder altså et skift fra at se på, hvad ting er eller gøres til, til at se på, hvordan verden er til stede. Mere radikalt vil jeg hævde, at verdens beskaffenhed for mennesket udspiller sig gennem atmosfæren. Det er gennem atmosfæren, at politik, samvær, magt, teknologi osv. tager form. Den usikkerhed, Böhme fremhæver, er netop betegnende for mange af mine informanters uafklarethed i forhold til, hvad - og ikke mindst hvordan - den atmosfære, de betegner „hygge“, egentlig er, idet den ganske givet også betegner en omfattende variation af situationer. Afklarethed er netop ikke en etnografisk realitet her.

I Böhmes teori om atmosfære er en tings egenskaber ikke noget, der hæfter sig til tingen, altså ikke noget, tingen har. Tingens egenskaber adskiller den ikke fra dens omgivelser. Det er tværtimod dens form for ncerveer, der adskiller den. Dette nærvær af ting er ,artikulationer af præsens“ og deres „,måder at være til stede på“ (op.cit.32). Hvad verden er, er således ikke defineret ved tingenes fysiske afgrænsning og forskellighed, men af deres fremtrædelsesmåder - deres ekstasier (op.cit.155-76).

Når det således kommer til spørgsmålet om, hvad verden er, og om der er flere verdener eller blot flere perspektiver på samme verden, viser ovenstående også, hvorledes selve spørgsmålet om en tings væren kan nuanceres yderligere. Om end ikke knyttet til en diskussion om flere verdener skriver Lars-Henrik Schmidt (2004:111) indsigtsfuldt, at det er umuligt at tale om, hvad en ting er, i hvert fald i filosofisk forstand. Det eneste, vi kan være sikre på, er, at den forgår. Schmidts bemærkning er interessant, da den netop peger på, at det værendes væren er en konstant bevægelig proces. På den ene side kunne man måske betegne Sussies hyggelys som netop dette: et objekt, der skabes og omformes i relationer, hvor repræsentation og præsentation smelter sammen eller helt undsiger sig adskillelsen. Det er de måder, hvorpå Sussie praktiserer såvel som taler om lyset, der definerer, hvad det er.

På den anden side kan man dog også bevæge sig videre og med Böhme tale om den måde, hvorpå verden bliver „tåget“ af atmosfæren, en verden, hvor 
følelser og tings fremtrædelsesformer konstant former fornemmelsen af verden som en tåge uden skarpe afgrænsninger. Med atmosfærens udflydende, diffuse grænser og intensiteter formes verden som et rum, der deles af mennesker, men som også i sig har muligheden for radikalt forskellige opfattelser hos personerne i de stemte rum, hvad enten det er Gilsenans skift fra at se neon til at se grønhed eller informanternes uklarhed i forholdet mellem lys og hygge. Det kan være mere eller mindre afklaret, hvad atmosfæren helt præcist er i en given situation, og dog er atmosfærer som del af social praksis også strukturerende for, hvordan verden skal være - i al sin uafklarethed.

Med begrebet ,atmosfære“ flyttes fokus fra, hvad fænomener repræsenterer og er, til, hvordan de fremtræder og dermed træder ind i menneskers erkendelser af verden. Som subjektive kendsgerninger er atmosfærer det mellem-voerende, der ikke kan reduceres til subjektet eller objektet, men altid er til stede, ikke blot $i$ relationen, men som selve relationen. Uafklaretheden om hyggen er netop forankret i denne dobbeltposition. Atmosfærens karakter kan ikke afgrænses endsige udpeges materielt eller geografisk, men er dog en ontologisk realitet, der toner eller „stemmer“ verden. Hvad verden er, ifølge vores informanter, afhænger med andre ord af den atmosfære, der subjektivt erfares i øjeblikket for beskrivelse eller praksis. Atmosfærer giver retning, men det er en uafklaret retning, der kan gøre os trygge, skræmte, gribe os eller forbigå vores opmærksomhed som noget, der „bare er“. De kan skabe intensitet, der kan fremprovokere en erkendelsesinteresse, hvor en tings væren momentant indsnævres, men som ikke desto mindre kan udfoldes igen, når intensiteten falder.

\section{Fra væren til fremtræden}

Mit sigte har her været at pege på, hvorledes erkendelsesinteresser og aspektbeskuelse ligger til grund for udsagn såsom „Her kommer hyggen“, for derved momentant at indkredse, hvad noget er og skal være. Trods det besnærende ved klare udsagn som Sussies har jeg søgt at vise, at antropologer også bør tage uafklarethederne for pålydende snarere end at forbigå dem. Uklarhed bør således tages teoretisk og metodisk alvorligt, mens informanternes klarhed må behandles med varsomhed.

Samtidig har det været sigtet at pege på, at den måde, verden fremtræder på, er tonet af en atmosfære, vi ofte kun i begrænset omfang opfatter, selvom den styrer den måde, vi fornemmer og praktiserer verden på. Informanterne og antropologen er ikke blot $i$, men også del af atmosfæren. I nogle tilfælde kan vi ikke italesætte den fornemmelse af verden, vi har, eller også er de begreber, vi bruger, for altomfattende til, at vi helt føler, at de er tilfredsstillende. Der er 
„noget“, der tages for givet, som vi ikke kan eller vil italesætte, men som alligevel former vores verdensforståelser og indretning. Der er en uklarhed i atmosfærens kvasiobjektive væsen, der taler til et patisk moment, der ikke ontologisk set er ingenting, men som samtidig er omgivet af en vaghed. Trods Gilsenans markante oplevelse af neonlys var det fornemmelsen af en grønhed, der „bare er“ for informanterne på en helt særlig måde, der formede deres verden og indlevelse i sufiritualet.

Samspillet mellem sprog, affekt, materialitet, normativitet og praksis som genstand for etnografisk analyse kan således udforskes gennem atmosfærens indflydelse på såvel antropologens som informantens italesættelse og praktisering af verden. Altså et fokus på, hvordan verden fremtrceder, snarere end på, hvad verden er. Atmosfærer er tåger, der ,toner“ denne fremtræden og fornemmelse af verden og dermed også den ene, anden eller overlappende verdeners værende.

\section{Noter}

1. Modsat en del nyere forskning (Mol 2002; Jensen 2010) anser jeg ontologi som betegnelse for det systematiske studie af det ontiske. Altså en eller anden form for systematisk refleksion over væren som værende.

2. Forfatteren takker Andreas Bandak, Frida Hastrup, Lars Højer, Birgitte Schepelern Johansen, Anja Kublitz, Matilde Lykke, Tim Flohr Sørensen, Michael Ulfstjerne, Sune Wøller, to anonyme læsere samt redaktionen for indsigt og fortsat uenighed i forbindelse med udarbejdelse af denne artikel.

3. Det skal bemærkes, at producenter i stigende omfang producerer pærer med samme farvetemperatur.

Søgeord: atmosfære, lys, uafklarethed, Danmark, Jordan, hygge

\section{Litteratur}

Alberti, Benjamin, Severin Fowles, Martin Holbraad, Yvonne Marshall \& Christopher Whitmore 2011 "Worlds Otherwise": Archaeology, Anthropology and Ontological Difference. Current Anthropology 52(6):896-912.

Appadurai, Arjun (ed.)

1986 The Social Life of Things: Commodities in Cultural Perspective. Cambridge: Cambridge University Press.

Ardener, Edwin

1992 Ritual og Socialt Rum. Tidsskriftet Antropologi 25:23-28.

Armstrong, Robert P.

1971 The Affecting Presence. An Essay in Humanistic Anthropology. Chicago: University of Illinois Press. 
Bijker, Wiebe E.

1995 Of Bicycles, Bakelites, and Bulbs: Towards a Theory of Sociotechnical Change.

Cambridge, MA: MIT Press.

Bille, Mikkel

2010 Seeking Providence Through Things. The Words of God versus Black Cumin. In: M. Bille, F. Hastrup \& T.F. Sørensen (eds.): An Anthropology of Absence.

Materializations of Transcendence and Loss. Pp. 167-84.

New York: Springer Press.

Bille, Mikkel \& Tim Flohr Sørensen

2007 An Anthropology of Luminosity. The Agency of Light. Journal of Material Culture 12(3):263-84.

2012 Materialitet. En indføring i kultur, identitet og teknologi.

Frederiksberg: Forlaget Samfundslitteratur.

Böhme, Gernot

1995 Atmosphäre: Essays zur neuen Ästhetik. Frankfurt am Main: Suhrkamp.

1998 Atmosphere as an Aesthetic Concept. Daidalos 68:112-15.

2001 Aisthetik: Vorlesungen über Ästhetik als allgemeine Wahrnehmungslehre. München: Wilhelm Fink Verlag.

2006 Architektur und Atmosphäre. München: Wilhelm Fink Verlag.

Bollnow, Otto Friedrich

1963 Mensch und Raum. Stuttgart: Kohlhammer.

Brennan, Teresa

2003 The Transmission of Affect. New York: Cornell University Press.

Bryant, Levi R.

2011 The Democracy of Objects. Ann Arbor: Open Humanities Press.

Cussins, Charis

1996 Ontological Choreography: Agency through Objectification in Infertility Clinics.

Social Studies of Science 26:575-610.

Dugdale, Anni

1999 Materiality: Juggling Sameness and Difference. In: J. Law \& J. Hassard (eds.):

Actor Network Theory and After. Pp. 113-35. Oxford: Blackwell.

Gad, Christopher \& Casper Bruun Jensen

2010 On the Consequences of Post-ANT. Science, Technology \& Human Values 35(1): 55-80.

Geertz, Clifford

1988 Works and Lives: The Anthropologist as Author. Cambridge: Polity.

Gilsenan, Michael

1982 Recognizing Islam. Religion and Society in the Modern Middle East. London: I.B. Tauris.

Gumbrecht, Hans Ulrich

2004 Production of Presence. What Meaning Cannot Convey.

Stanford: Stanford University Press.

2006 Erinnerung an Herkünfte. Frankfurter Allgemeine Zeitung, 17. januar 
Heidegger, Martin

2007 [1927] Væren og tid. Aarhus: Klim.

Henare, Amiria, Martin Holbraad \& Sari Wastell (eds.)

2007 Thinking Through Things. Theorising Artefacts Ethnographically. London: Routledge.

Holbraad, Martin

2007 The Power of Powder: Multiplicity and Motion in the Divinatory Cosmology of Cuban Ifá (or Mana, again). In: A. Henare, M. Holbraad \& S. Wastell (eds.): Thinking Through Things. Therorising Artefacts Ethnographically. Pp. 189-225. London: Routledge.

$2010 \quad$ Can the Thing Speak? OAC PRESS Working Papers Series 7.

Højer, Lars

2013 Hvilke ting? Hvilke relationer? Hvilke verdener?

Tidsskriftet Antropologi 67:47-49.

Jensen, Casper Bruun

2010 Ontologies for Developing Things. Making Health Care Futures through Technology. Rotterdam: Sense Publishers.

Laet, Marianne de \& Annemarie Mol

2000 The Zimbabwe Bush Pump: Mechanics of a Fluid Technology. Social Studies of Science 30(2):225-63.

Law, John

After Methods. Mess in Social Science Research. London: Routledge.

2011 What's Wrong with a One-World World. Præsenteret ved Center for the Humanities, Wesleyan University, Middletown, Connecticut, 19. september. http://www.heterogeneities.net/publications/Law2011WhatsWrongWithAOneWorldWorld.pdf.

Law, John \& Annemarie Mol

2008 The Actor-Enacted: Cumbrian Sheep in 2001. In: C. Knappett \& L. Malafouris (eds.): Material Agency. Towards a Non-Anthropocentric Approach. Pp. 57-77. New York: Springer.

Law, John \& Vicky Singleton

2005 Object Lessons. Organization 12(3):331-55.

Linnet, Jeppe Trolle

2011 Money Can’t Buy Me Hygge. Danish Middle-Class Consumption, Egalitarianism and the Sanctity of Inner Space. Social Analysis 55(2):21-44.

Mol, Annemarie

1999 Ontological Politics. A Word and Some Questions. In: J. Law \& J. Hassard (eds.): Actor Network Theory and After. Pp. 74-89. Oxford: Blackwell.

2002 The Body Multiple: Ontology in Medical Practice. Durham: Duke University Press.

Navaro-Yashin, Yael

2012 The Make-Believe Space. Affective Geography in a Post War Polity. Durham: Duke University Press.

Nielsen, Morten

2013 Vi bebor mangfoldige verdener. Tidsskriftet Antropologi 67:23-28. 
Sartre, Jean-Paul

1977 Sketch for a Theory of the Emotions. London: Methuen \& Co. Ltd.

Schmidt, Lars-Henrik

2004 Moderne snavs. Et socialanalytisk perspektiv på forfaldet. I: M. Kragelund (red.): Ting og tingester. København: Danmarks Pædagogiske Universitet.

Schmitz, Hermann

2011 Die Lehre vom Gefühl in der Neuen Phänomenologie. Præsenteret ved Teologisk Fakultet, Københavns Universitet, 11. marts. http://www.teol.ku.dk/afd/ast/ arrangementer/200911020/Herman_Schmitz_Die_Lehre_von.PDF/.

Schmitz, Hermann, Rudolf Owen Müllan \& Jan Slaby

2011 Emotions Outside the Box - the New Phenomenology of Feeling and Corporeality. Phenomenology and the Cognitive Sciences 10(2):241-59.

Straus, Erwin W.

1966 Phenomenological Psychology. The Selected Papers of Erwin W. Straus. New York: Basic Books.

Tellenbach, Hubertus

1968 Geschmack und Atmosphäre. Salzburg: Otto Müller Verlag.

Thibaud, Jean-Paul

2011 Sensory Design. The Sensory Fabric of Urban Ambiances. Senses and Society 6(2):203-15.

Viveiros de Castro, Eduardo

1998 Cosmological Deixis and Amerindian Perspectivism. Journal of the Royal Anthropological Institute 4(3):469-88.

Wittgenstein, Ludwig

2009 [1939] Philosophical Investigations. Oxford: Wiley-Blackwell. 
